\title{
ティグ溶接中の電極における添加物の動的挙動シミュレーション*
}

\author{
小西 恭平**, 田中 学 ${ }^{* * *}$, 茂田 正哉 ${ }^{* * *}$, 石田 和也 ${ }^{* * *}$, 黒川 顕稔**,
} 瀧田 朋広 ${ }^{* * * *}$, 中林 誠治****, 辻 あゆ里 ${ }^{* * * * *}$

\begin{abstract}
Numerical Analysis of Dynamic Behavior of Additives in Electrode During TIG Welding Process*
\end{abstract}
by KONISHI Kyohei ${ }^{* *}$, TANAKA Manabu ${ }^{* * *}$, SHIGETA Masaya ${ }^{* * *}$, ISHIDA Kazuya ${ }^{* * *}$, KUROKAWA Akitoshi**, TAKIDA Tomohiro ${ }^{* * * *}$, NAKABAYASHI Seiji ${ }^{* * * *}$ and TSUJI Ayuri ${ }^{* * * * *}$

\begin{abstract}
Consumption of tungsten electrode during TIG welding process is one of unavoidable problems and many studies have been progressed to improve the consumption resistance. In general, some kinds of oxides $\left(\mathrm{ThO}_{2}, \mathrm{La}_{2} \mathrm{O}_{3}, \mathrm{Ce}_{2} \mathrm{O}_{3}\right)$ are added to the tungsten electrode in order to make the thermionic emission easy and control the electrode temperature below the melting point of tungsten. However, the lifetime of electrode is still limited within a few hours because the additives evaporate and a lack of additives is caused on the electrode surface. In this study, numerical simulations which focus on the evaporation and diffusion phenomena of additives in the electrode were performed in order to clarify a consumption mechanism and identify effective factors for the lifetime of electrode.

As time passed, the mass concentration of additive decreased due to an evaporation phenomenon whereas the additive was supplied from inside to outside of electrode by a diffusion phenomenon. When the degree of coverage of additive decreased, the electrode temperature quickly increased and it reached the melting point of tungsten. The lifetime of electrode was strongly depended on the physical properties of additives such as diffusion constant and melting point of their oxides.
\end{abstract}

Key Words: Numerical analysis, TIG welding process, Oxide, Lifetime of electrode, Evaporation and diffusion phenomena, Consumption mechanism, Physical properties of additive

1. 緒言

ティグ（Tungsten Inert Gas: TIG）溶接は, アークプラズ マを利用した非消耗電極式の溶接プロセスであり，溶接入 熱と溶加材の供給量を独立して制御でき全姿勢での溶接が 容易であることから，ものづくり分野において重要な溶接 技術となっている. このティグ溶接では一般的に陰極とな るタングステン電極に数 wt. \%の酸化物が添加されている. これは電極にタングステンに比べて仕事関数の低い酸化物 を添加することで電極からの電子放出を容易にし, 電極の 動作温度を低下させることで電極の溶融を防ぐためである. しかしながら, 長時間のアーク放電やアーク点弧・消弧の 繰り返しにより電極が消耗することは避けられず, この課 題を解決するためアークスタートの安定性や耐消耗性に優 れたより良い電極の研究が進められている。

Sadek ら ${ }^{1)}$ はングステン電極の消耗に着目し, ティグ溶 接試験後の電極先端のマクロ観察を行い, トリア（酸化卜

\footnotetext{
*受付日 平成29年 1 月17日 受理日 平成29年 3 月11日

**学生員 大阪大学接合科学研究所 Student Member, Joining and Welding Research Institute, Osaka University

***正 員 大阪大学接合科学研究所 Member, Joining and Welding Research Institute, Osaka University $\begin{array}{lllll}\text { *****株式会社アライドマテリアル A.L.M.T. Corp. } & \text { A.T. }\end{array}$ *****正 員 株式会社アライドマテリアル Member, A.L.M.T. Corp.
}

リウム) やランタナ（酸化ランタン）等の酸化物の融点お よび仕事関数が電極の消耗に大きく影響を与えていること を明らかにしている。

田中ら 2)は高電流条件における電極の消耗試験および試験 後の電極表面や断面の観察を行い, 長時間アークプラズマ を点弧し続けると電極内に空孔形成や酸化物の消失が見ら れ，それに伴って急激に電極の消耗が進むことを明らかに している.

さらに近年では数值計算技術の進歩が目覚しく，数值シ ミュレーションによってアーク溶接プロセスの解析が進め られており，ティグ溶接の電極に関する研究も数多く報告 されている.

山本ら ${ }^{3)}$ は電極, アークプラズマならびに母材を一体化し た二次元軸対称モデルを用いて純タングステン電極とトリ ア入り電極について点弧から 5 分後の電極の先端形状を模 擬した計算を行い，電極の先端形状がアークプラズマ特性 に与える影響について考察している. 結果として, アーク 点弧後すぐに電極の先端が溶融し半球状になる純タングス テン電極は, 先端が溶融せず尖った形状を維持できるトリ ア入り電極に比べてアーク圧力およびアークプラズマ中心 部の温度が大きく低下した。一方で, 電極の最高温度は純 タングステン電極で $4079 \mathrm{~K}$, トリア入り電極で $3776 \mathrm{~K}$ であっ た.これは Haidar らの実験結果 ${ }^{4}$ ともよく一致している。つ 
まり, 純タングステン電極はトリア入り電極に比べてアー クプラズマの温度は低いが電極先端の温度は高く, 電極の 消耗が激しくなることが示唆された。これはタングステン の仕事関数 $4.5 \mathrm{eV}$ がトリウムの仕事関数 $2.8 \mathrm{eV}$ に比べて大 きいことに起因している。

田中ら5)はトリア，ランタナおよびセリア（酸化セリウム） 入り電極について酸化物の融点を考慮した数值解析モデル を構築し，アークプラズマ特性に関して酸化物の仕事関数 だけではなく酸化物の融点も重要であることを示している.

また，溶接施工現場での電極のメンテナンス回数を減ら し生産性および経済性を向上させることにおいて電極の長 寿命化が課題となっており, 上述の研究に加えティグ溶接 におけるタングステン電極の寿命評価の研究も進められて いる.

Casado らは高電流条件においてジュール発熱がトリア入 り電極の寿命に与える影響を電極軸上における添加物の一 次元拡散モデルを解くことで評価している，ここでは，電 極からのトリウムの蒸発量を計算する上で電極表面におけ るトリウムの濃度が重要であることから ${ }^{7)}$, 表面におけるト リウムの保存式を解きトリウムの蒸発量を表面の温度とト リウムの濃度から求めている.

西山ら ${ }^{8)}$ はジュール発熱だけでなくプラズマからの熱伝導 を考慮したアークプラズマの熱流動解析を行い, 電極の形状 や電流値の違いが電極の寿命に与える影響を評価している.

これらの電極の長寿命化に関する研究は時間変化に伴う 添加物の挙動を定量的に評価し，電極先端における添加物 の消失による仕事関数の増大に伴い電極の温度が上昇する 現象を捉えている．しかしながら，電極先端において電極 表面からの添加物の蒸発速度は内部からの拡散によって供 給される速度よりも大きいため, 電極軸上での添加物の濃 度が電極側面での濃度と一致しないという点は考慮に含ま れていない，そのため，これらの研究では電極の寿命を実 際よりも長く評価している可能性があり, 正確な電極の寿 命評価ができているとは言い難い.

本研究では，耐消耗性に優れたより良い電極の開発に向 けて，ティグ溶接中の電極における添加物の蒸発および拡 散現象について二次元空間での数值シミュレーションを行 い, 電極表面だけでなく電極内部の添加物の挙動を可視化 した。また電極の長寿命化にも着目し，添加物の物性值を 変化させることで時間経過に伴う電極の消耗に影響を与え る因子を特定し，それらの役割について調査した。

\section{2. 数値解析モデル}

\section{1 モデルの概要}

本研究で構築した数值解析モデルは, 電極における添加 物の蒸発および拡散現象を取り扱う蒸発・拡散モデルとティ グ溶接中におけるアークプラズマ現象を取り扱うティグ溶 接モデルを組み合せた一体化モデルである．Fig. 1 に一体化
モデルで用いた数值計算アルゴリズムのフローチャートを 示す。ティグ溶接モデルでは定常状態のアークプラズマ現 象を計算し，全ての格子点におけるエンタルピー，流速， 圧力および電位について 1 ステップ前の計算結果との変化 が $0.1 \%$ 以下となった場合，計算は収束したと見なし電極の 温度分布が出力される. 一方, 収束条件が満たされない場合, 圧力を補正し各支配方程式を解く動作を繰り返し行う。蒸 発・拡散モデルは非定常計算であり，まずティグ溶接モデ ルで計算された電極の温度分布が入力された後, 時間を $\Delta t$ 進め，各計算格子における拡散係数ならびに電極表面とな る計算格子における蒸発速度が計算される。ただし，蒸発・ 拡散モデルの 1 タイムステップ $\Delta t$ 内において電極の温度分 布は変化しないものと仮定している，本研究において $\Delta t$ は 10秒とした，次に拡散方程式を解くことで各計算格子にお ける添加物の数密度を得る。蒸発・拡散モデルの収束判定 はティグ溶接モデルと同様に全ての格子点における添加物 の数密度について, 1 ステップ前の計算結果との変化が $0.1 \%$ 以下かどうかによって行う。この操作を 6 夕イムステップ 行った後，収束条件が満たされた場合，各計算格子の添加 物の表面占有率から電極の仕事関数が計算され，ティグ溶 接モデルへの入力データとして出力される。この一連の計 算は蒸発・拡散モデルでの時刻が計算終了時刻になるまで 繰り返し行われる。また，本研究で取り扱う2つのモデル は計算格子のサイズおよび数が異なるため，モデル間にお ける温度分布および電極の仕事関数デー夕の輸送にはバイ リニア補間を用いた。

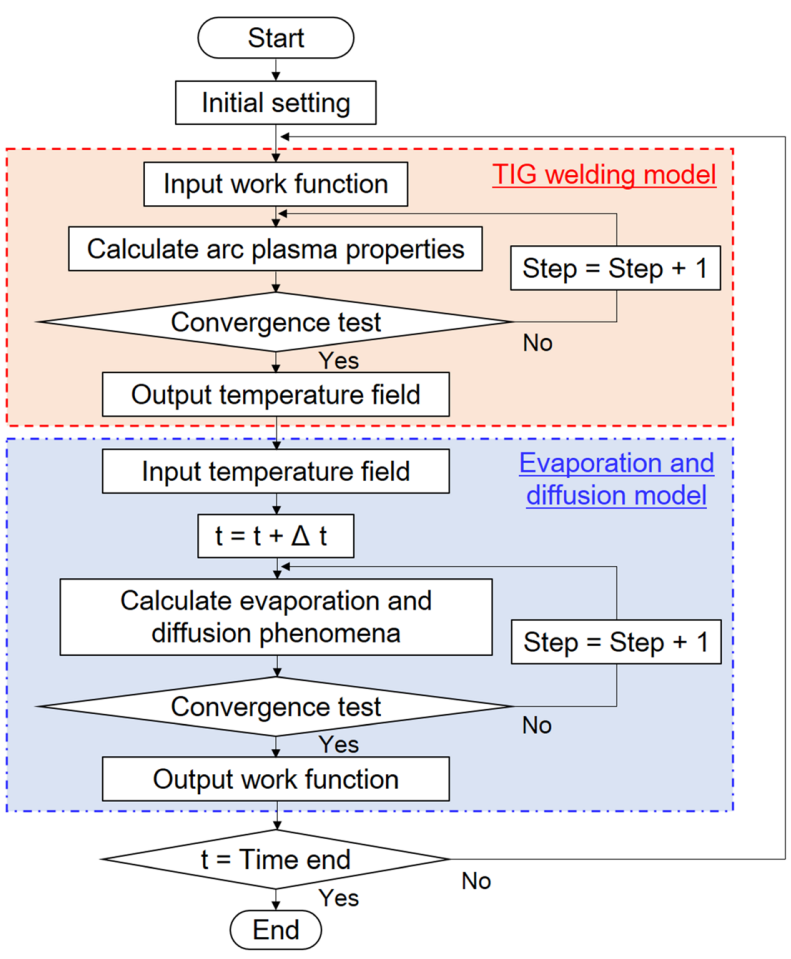

Fig.1 Flowchart of calculation for the unified model 


\section{2 蒸発・拡散モデル}

蒸発・拡散モデルの計算対象は直径 $3.2 \mathrm{~mm}$, 電極先端角 度 $60^{\circ}$, 先端に直径 $0.4 \mathrm{~mm}$ の面取りを施したタングステン 電極である。ただし，3.1節では $2.0 \mathrm{wt} . \%$ トリア入りタング ステン電極を，3.2節では $2.0 \mathrm{wt} . \%$ トリア入りタングステン 電極に加え $2.0 \mathrm{wt} . \%$ ランタナ入りタングステン電極および 2.0 wt. \% セリア入りタングステン電極を想定している. Fig. 2 に蒸発・拡散モデルの計算領域を示す。蒸発・拡散モ デルは二次元円筒座標系の軸対称を仮定しており，軸方向 の領域寸法は面取りを施した電極先端から $5.0 \mathrm{~mm}$ とした. Fig. 2 において $\mathrm{AB}$ が面取りを施した範囲である。なお，本 稿では以下 $\mathrm{ABCE} て ゙$ 囲まれる範囲を円錐部, OECD で囲ま れる範囲を円柱部と呼称する。

電極における添加物の拡散は酸化物ではなく添加元素の 原子が拡散するものと仮定し，蒸発速度および拡散係数の 計算に必要な物性值は全て添加元素の原子が有する物性值 を用いた ${ }^{9,10)}$ 。例えば $2.0 \mathrm{wt}$ \% \% トリア入り電極の場合, 酸化 物であるトリアではなくトリウム原子の物性值を用いた. これは, ティグ溶接中において電極先端部では酸化物が夕 ングステンによって還元され，添加元素の原子になると考 えられるからである ${ }^{9}$.

以下に蒸発・拡散モデルで用いる支配方程式を示す。 電極での添加物の拡散方程式 :

$$
\frac{\partial n}{\partial t}=\frac{1}{r} \frac{\partial}{\partial r}\left(r D(T) \frac{\partial n}{\partial r}\right)+\frac{\partial}{\partial z}\left(D(T) \frac{\partial n}{\partial z}\right)
$$

ここで, $r$ は半径方向距離, $z$ は軸方向距離, $t$ は時間, $n$

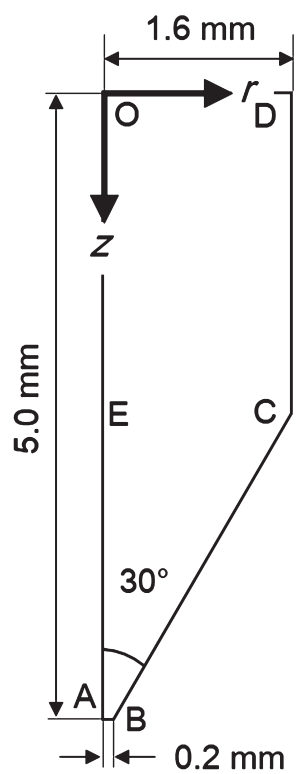

Fig.2 Schematic illustration of computational domain of the evaporation and diffusion model
は添加元素の原子の数密度, $T$ は温度である. $D(T)$ は温度 によって決定される拡散係数であり, 拡散定数 $D_{0}$, 活性化 エネルギー $Q$, 気体定数 Rを用いて次式のように定義される. 拡散係数に関するアレニウスの式 :

$$
D(T)=D_{0} \exp \left(\frac{-Q}{\mathrm{R} T}\right)
$$

電極表面において添加物は電子放出に関して大きな役割 を担っており，添加物の表面占有率は電極とアークプラズ マの境界における電気伝導率を左右する重要な因子である. 半径方向および軸方向の添加物の表面占有率は拡散速度や 蒸発速度の影響を考慮した以下の式で求められる. ただし, 初期状態および酸化物の融点以下においては酸化物の質量 濃度から酸化物の体積率を求め電極表面における表面占有 率とした。 2.3節の電気伝導率の考え方において詳しく記述 するが, 本研究で想定している 2.0 wt. \%の酸化物入り電極 では初期状態の表面占有率は $\varphi=0.05$ である.

電極表面における添加物の保存式 :

(半径方向)

$$
N_{0} \frac{\partial \varphi_{r}}{\partial t}=-\gamma_{\text {eff }}\left(T, \varphi_{r}\right)-\left.D(T) \frac{\partial n}{\partial r}\right|_{r=r^{*}}
$$

(軸方向)

$$
N_{0} \frac{\partial \varphi_{z}}{\partial t}=-\gamma_{\text {eff }}\left(T, \varphi_{z}\right)-\left.D(T) \frac{\partial n}{\partial z}\right|_{z=z^{*}}
$$

ここで， $\varphi_{r}$ および $\varphi_{z}$ は半径方向および軸方向の添加物の 表面占有率, $N_{0}$ は電極表面における添加元素の原子の単位 表面積あたりの初期数密度, $\gamma_{\mathrm{eff}}$ は添加物の正味の蒸発率, $r^{*}$ および $z^{*}$ は半径方向および軸方向の終端の座標である. 本研究では初期数密度は $N_{0}=4.2 \times 10^{18} \mathrm{~m}^{-2}$ とした ${ }^{11)}$. 添加物の蒸発率：

$$
\gamma_{\text {eff }}(T, \varphi)=\varphi \varepsilon \gamma_{0}(T) \exp \left(-\frac{\mathrm{e} H(\varphi)}{\mathrm{k}_{\mathrm{B}} T}\right)
$$

ここで， $\varepsilon$ は吸着を考慮した蒸発に用いる定数， $H_{(\varphi)}$ は吸 着熱, e は電子素量, $\mathrm{k}_{\mathrm{B}}$ はボルツマン定数である。ただし, 蒸発率の算出に用いる電極温度の最大值はタングステンの 融点である $3653 \mathrm{~K}$ とし, 添加物の表面占有率 $\varphi$ は添加物が 完全に電極表面を覆った状態で最大の 1.0 であり，1.0より 大きくならないものとした，真空下での添加物の蒸発率を 表す $\gamma_{0}(T)$ はプランク定数 $\mathrm{h}_{\mathrm{plank}}$ を用いて次式のように定義さ れる ${ }^{12)}$.

$$
\gamma_{0}(T)=\left(\frac{\mathrm{k}_{\mathrm{B}} T}{\mathrm{~h}_{\text {plank }}}\right) N_{0}
$$

ティグ溶接モデルの計算において必要とされるタングス テン電極表面の仕事関数 $\varnothing_{\mathrm{w}}$ は Gyftopoulos らの実験結果 ${ }^{13}$ により表面占有率を用いて次式のように表される. 
電極表面の仕事関数 :

$\varnothing_{\mathrm{w}}=\varnothing_{\min }+\left(\varnothing_{\max }-\varnothing_{\min }\right)(1-\varphi)^{2}$

ここで, $\varnothing_{\min }$ は仕事関数の最小値, $\varnothing_{\max }$ は仕事関数の最 大值であり， $\varnothing_{\min }$ には添加物の仕事関数を， $\varnothing_{\max }$ には夕ン グステンの仕事関数を用いた ${ }^{5)}$.

蒸発・拡散モデルにおける境界条件を以下に示す。 計算範囲左端 $(\mathrm{OA})$ 抢よび計算範囲右端 $(\mathrm{CD})$ ：

$$
\frac{\partial n}{\partial r}=0
$$

計算範囲上端 $(\mathrm{OD})$ ：

$$
\frac{\partial n}{\partial z}=0, \quad n=n_{0}
$$

計算範囲下端 $(\mathrm{AB})$ :

$$
\frac{\partial n}{\partial z}=0
$$

計算範囲右下端 $(\mathrm{BC})$ ：

$$
\frac{\partial n}{\partial z}=0, \quad \frac{\partial n}{\partial r}=0
$$

ここで, $n_{0}$ は添加元素の原子の初期数密度である.

蒸発・拡散モデルに打ける計算領域は Patankar の有限体 積法による離散化手法 ${ }^{14}$ に従って Fig. 3 に示すように半径方 向に 162 ならびに軸方向に 579 の均一型コントロールボ リュームに分割され，離散化された拡散方程式は 3 重対角 行列解法（Tri-Diagonal Matrix Algorithm: TDMA）を用いた 陰解法 ${ }^{15}$ によって解かれる。計算格子のサイズは半径方向 $1.00 \times 10^{-2} \mathrm{~mm}$, 軸方向 $8.66 \times 10^{-3} \mathrm{~mm}$ である. 添加物の蒸 発は計算領域の境界面である右端 $(\mathrm{CD})$, 右下端 $(\mathrm{BC})$ およ び下端 $(\mathrm{AB})$ の計算格子に扔いて計算される。また，添加物 は電極表面となる計算格子から半径方向抢よび軸方向へそ れぞれ蒸発するものとした。

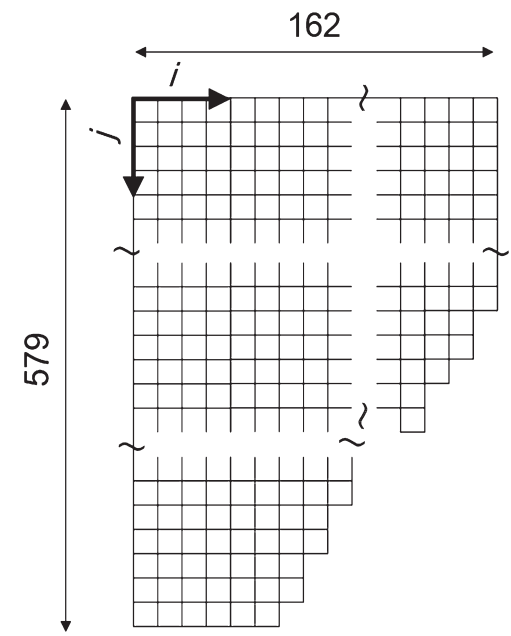

Fig. 3 Computational meshes of the evaporation and diffusion model

\section{3 ティグ溶接モデル}

ティグ溶接モデルは陰極領域（タングステン電極），アー クプラズマ領域掞よび陽極領域（水冷銅）を計算対象とし ており，蒸発・拡散モデルと同様に二次元円筒座標系の軸 対称を仮定している. Fig.4にティグ溶接モデルの計算領域 を示す．中心軸上の陽極表面 B から中心軸に沿って $10.0 \mathrm{~mm}$ 上方に原点をとり $\mathrm{r}$ 軸扔よび $\mathrm{z}$ 軸を設定した。計算領域の寸 法は半径方向 $25 \mathrm{~mm}$ （㓌極：1.6 mm, 陽極： $25 \mathrm{~mm}$ ), 軸方 向 $45 \mathrm{~mm}$ (陰極 : $30 \mathrm{~mm}$, アーク長 : $5 \mathrm{~mm}$, 陽極 : $10 \mathrm{~mm}$ ) である.タングステン電極は蒸発・拡散モデルと同様の寸 法とした。シールドガスは純アルゴンとし，流量は $15 \mathrm{~L} / \mathrm{min}$ とした。 上記の計算領域は蒸発・拡散モデルとは異なり半 径方向に 70 抢よび軸方向に 95 の不均一型コントロールボ リュームに分割された後，離散化された各支配方程式は SIMPLEC (Semi Implicit Method for Pressure Linked EquationConsistent）法 ${ }^{16}$ を用いて数值的に解かれる. ティグ溶接モデ ルに扔ける最小の計算格子サイズは電極先端において半径 方向 $2.68 \times 10^{-3} \mathrm{~mm}$, 軸方向 $1.00 \times 10^{-2} \mathrm{~mm}$ である.

ティグ溶接モデルでは下記の仮定の下，数值計算が行わ れる。（i）アークプラズマは電子温度と重粒子温度が同じで ある局所熱平衡状態 (Local Thermodynamic Equilibrium: LTE) にある.（ii）流れは全て定常・層流である。(iii)アークプラ ズマからの放射に関して自己吸収は考慮しない。

数值計算に用いられるエンタルピー, 比熱, 密度, 粘性, 熱伝導度㧍よび電気伝導率といったアークプラズマの物性 には Murphy らの平衡組成計算17によって得られたデー夕を 用いた。 ティグ溶接モデルは陰極，アークプラズマ拉よび 陽極を一つの計算領域として扱うことができるため，それ ぞれの領域に関して個別の保存式を解く必要はなく, 統一 された保存式が定義される。数值計算では以下に示す質量,

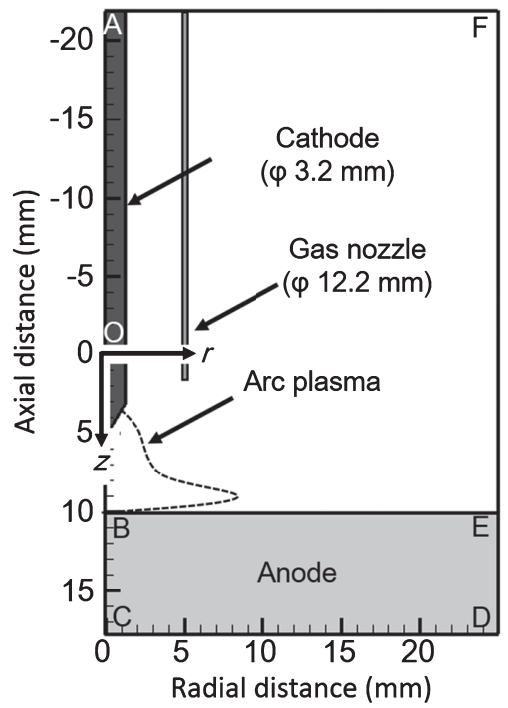

Fig. 4 Schematic illustration of computational domain of the TIG welding model 
運動量, エネルギーおよび電流に関する保存式を解くこと で計算領域全体の温度, 流速および電位の二次元場が得ら れる。

質量保存式：

$$
\frac{1}{r} \frac{\partial}{\partial r}\left(r \rho v_{r}\right)+\frac{\partial}{\partial z}\left(\rho v_{z}\right)=0
$$

運動量保存式：

(半径方向)

$$
\begin{aligned}
& \frac{1}{r} \frac{\partial}{\partial r}\left(r \rho v_{r}{ }^{2}\right)+\frac{\partial}{\partial z}\left(\rho v_{z} v_{r}\right) \\
& \quad=-\frac{\partial p}{\partial r}-j_{z} B_{\theta}+\frac{1}{r} \frac{\partial}{\partial r}\left(2 r \eta \frac{\partial v_{r}}{\partial r}\right)+\frac{\partial}{\partial z}\left(\eta \frac{\partial v_{r}}{\partial z}+\eta \frac{\partial v_{z}}{\partial r}\right)-2 \eta \frac{v_{r}}{r^{2}}
\end{aligned}
$$

(軸方向)

$$
\begin{aligned}
& \frac{1}{r} \frac{\partial}{\partial r}\left(r \rho v_{r} v_{z}\right)+\frac{\partial}{\partial z}\left(\rho v_{z}^{2}\right) \\
& \quad=-\frac{\partial p}{\partial z}+j_{r} B_{\theta}+\frac{\partial}{\partial z}\left(2 \eta \frac{\partial v_{z}}{\partial z}\right)+\frac{1}{r} \frac{\partial}{\partial r}\left(r \eta \frac{\partial v_{r}}{\partial z}+r \eta \frac{\partial v_{z}}{\partial r}\right)+\rho g
\end{aligned}
$$

エネルギー保存式：

$$
\begin{aligned}
& \frac{1}{r} \frac{\partial}{\partial r}\left(r \rho v_{r} h\right)+\frac{\partial}{\partial z}\left(\rho v_{z} h\right) \\
& \quad=\frac{1}{r} \frac{\partial}{\partial r}\left(\frac{r \kappa}{c_{p}} \frac{\partial h}{\partial r}\right)+\frac{\partial}{\partial z}\left(\frac{\kappa}{c_{p}} \frac{\partial h}{\partial z}\right)+\frac{j_{r}{ }^{2}+j_{z}^{2}}{\sigma}-U
\end{aligned}
$$

電流保存式 :

$$
\frac{1}{r} \frac{\partial}{\partial r}\left(r \sigma \frac{\partial V}{\partial r}\right)+\frac{\partial}{\partial z}\left(\sigma \frac{\partial V}{\partial z}\right)=0
$$

ここで, $r$ は半径方向距離, $z$ は軸方向距離, $\rho$ は密度, $v_{r}, v_{z}$ はそれぞれ速度の半径方向成分と軸方向成分, $p$ は圧力, $\eta$ は粘性係数, $j_{r}, j_{z}$ はそれぞれ電流密度の半径方向成分と軸 方向成分， $B_{\theta}$ は周方向の磁束密度， $g$ は重力加速度， $h$ は工 ンタルピー, $\kappa$ は熱伝導度, $c_{p}$ は定圧比熱, $\sigma$ は電気伝導率, $U$ は放射損失, $V$ は電位である。

電流密度 $j_{r}, j_{z}$ はオームの法則によって導かれる. また, 運動量保存式に含まれる周方向の磁束密度 $B_{\theta}$ は真空の透磁 率 $\mu_{0}$ を用いてアンペールの法則によって定義される. オームの法則 :

$$
j_{r}=-\sigma \frac{\partial V}{\partial r} \quad j_{z}=-\sigma \frac{\partial V}{\partial z}
$$

アンペールの法則 :

$$
\frac{1}{r} \frac{\partial}{\partial r}\left(r B_{\theta}\right)=\mu_{0} j_{z}
$$

ティグ溶接モデルにおける境界条件を以下に示す。 計算範囲右端 (FD) :

$$
T=300 \mathrm{~K}, \quad v_{r}=0, \quad v_{z}=0
$$

計算領域左端 $(\mathrm{AC})$ ：

$$
\frac{\partial T}{\partial r}=0, \quad \frac{\partial V}{\partial r}=0, \quad \frac{\partial v_{z}}{\partial r}=0, \quad v_{r}=0
$$

計算範囲上端 $(\mathrm{AF})$ ：

$$
T=300 \mathrm{~K}, \quad v_{r}=0
$$

計算範囲下端（DC）：

$$
T=300 \mathrm{~K}, \quad V=0, \quad v_{r}=0, \quad v_{z}=0
$$

電極および母材において流れの速度はゼロとする。また，

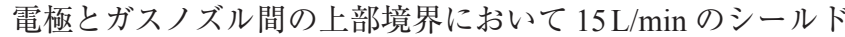
ガス流量に相当する流速が与えられる。電極の上端境界で は設定電流值を電極断面積で除して得られる電流密度 $j_{z}$ が 均一に与えられている。また，この境界上端における電位 は $\partial V / \partial z=-j_{z} / \sigma て ゙$ 定義されている．計算領域下端における電 位はゼロとした。

陰極であるタングステン電極の表面境界では式(11)で示 されているエネルギー輸送現象に加え，熱電子放出による 冷却やイオンの再結合による加熱および熱放射による冷却 を考慮する必要があり, 加えられるエネルギー流束 $F_{\mathrm{c}}$ は次 式で表される。

$$
F_{\mathrm{c}}=-\varepsilon_{\mathrm{c}} \alpha T^{4}-\left|j_{e}\right| \varnothing_{\mathrm{w}}+\left|j_{i}\right| V_{i}
$$

ここで, $\varepsilon_{\mathrm{c}}$ は電極の放射率， $\alpha$ はステファン・ボルッマン 定数, $j_{e}$ は電子電流密度, $\varnothing_{\mathrm{w}}$ は電極の仕事関数, $j_{i}$ はイオン 電流密度, $V_{i}$ はシールドガスの電離電圧である。電子電流 密度 $\left|j_{e}\right|$ は次のリチャードソン・ダッシュマンの式に基づい て決定される. また，イオン電流密度 $j_{i}$ は $|j|-\left|j_{e}\right|$ によって 計算される。

リチャードソン・ダッシュマンの式：

$$
\left|j_{e}\right|=A T^{2} \exp \left(-\frac{\mathrm{e} \varnothing_{\mathrm{w}}}{\mathrm{k}_{\mathrm{B}} T}\right)
$$

$A$ はリチャードソン定数である.

一方，陽極の表面境界では電子吸収による加熱および熱 放射による冷却をエネルギー流束 $F_{\mathrm{A}}$ として加える。ただし， Lowke ら ${ }^{18)}$ と同様に母材表面におけるイオン電流はゼロであ りイオン加熱は存在しないとした.

$$
F_{\mathrm{A}}=-\varepsilon_{\mathrm{A}} \alpha T^{4}+\left|j_{e}\right| \varnothing_{\mathrm{A}}
$$

$\varepsilon_{\mathrm{A}}$ は陽極の放射率， $\varnothing_{\mathrm{A}}$ は陽極の仕事関数である.

アーク放電時に陰極であるタングステン電極の表面にお いて生じる熱電子放出現象は電極の表面状態および添加物 の表面占有率によって大きく変化するため, 本研究では電 


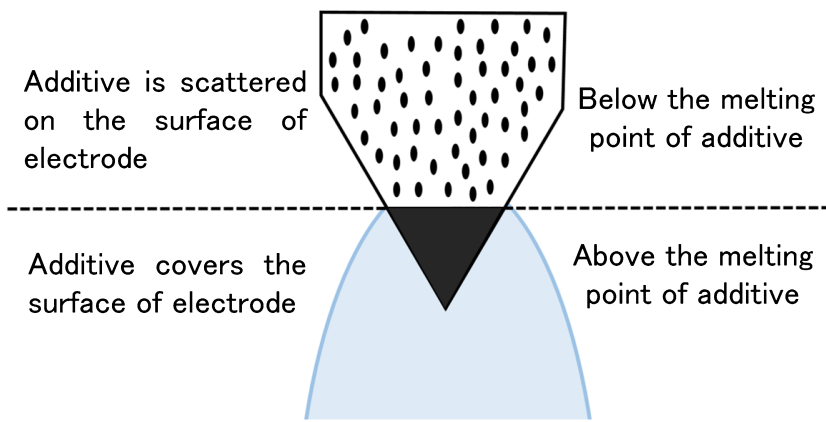

Fig. 5 Schematic illustration of distribution of additive on the electrode surface

極表面に接するアークプラズマの電気伝導率 $\sigma_{\mathrm{s}}$ を Fig. 5 に 示すコンセプトに基づき以下の式で計算する.

(i)電極の表面温度が酸化物の融点以下の場合 :

$$
\sigma_{\mathrm{s}}=5.0 \% \sigma_{\mathrm{a}}
$$

（ii）電極の表面温度が酸化物の融点以上の場合：

$$
\sigma_{\mathrm{s}}=\left(\varphi+(1-\varphi) R_{\mathrm{w}}\right) \sigma_{\mathrm{a}}
$$

ここで， $\sigma_{\mathrm{a}}$ は Murphyらの平衡組成計算 ${ }^{17)}$ によって得られ た電気伝導率, $\varphi$ は蒸発・拡散モデルで得られる添加物の 表面占有率, $R_{\mathrm{w}}$ は式(20)で示すようにタングステンからの 熱電子放出密度を添加物からの熱電子放出密度で除した值 であり，電気伝導率に対するタングステンからの熱電子放 出の影響の大きさ（以下，電気伝導率に対するタングステ ンの影響度）を表している。

$$
R_{\mathrm{w}}=\frac{\left|j_{e}(\mathrm{~W})\right|}{\left|j_{e}(\mathrm{Th})\right|}
$$

Fig. 6 に各電極表面温度における電気伝導率に対する夕ン グステンの影響度の変化を示す。酸化物はトリアでありト リアの融点 $(3323 \mathrm{~K})$ 以下の温度域における電気伝導率に 対するタングステンの影響度は破線で描かれている。電極 の表面温度が酸化物の融点以下の場合, 電気伝導率に対す るタングステンの影響度は小さいため, タングステンに比 べて仕事関数の低い酸化物が電極表面からの電子放出を全 て担うと考え, Fig. 7 に示すように電極表面に接するアーク プラズマの電気伝導率を通常の $5 \%$ の值とした。これは酸 化物の融点以下では電極表面において島状（約 $5 \mu \mathrm{m} ）$ の固 体の酸化物が分散して存在しており ${ }^{1)}$, 酸化物の含有率を体 積％に変換すると $5 \%$ になるからであり，電極表面積を $S$ として電流は $\vec{I}=-S \sigma \nabla V$ で表されるので，5\%表面積率を $5 \%$ 電気伝導率に置き換えられるからである。一方，電極の 表面温度が酸化物の融点以上の温度範囲では液体となった 添加物が電極表面を覆うように存在し ${ }^{19,20)}$, 添加物とタング ステンの両方から電子放出が行われるとした。 この場合, 電極表面に接するアークプラズマの電気伝導率は添加物の

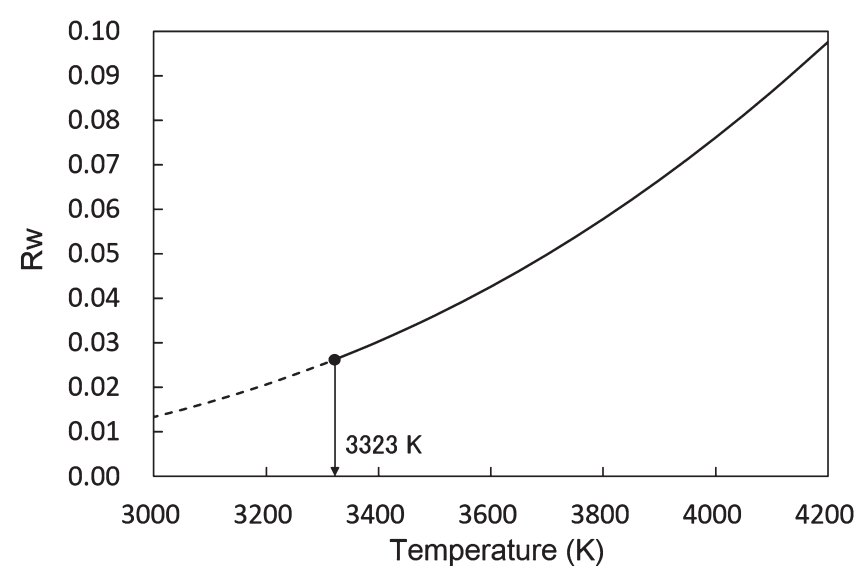

Fig. 6 Relationship between the ratio of thermionic emission of tungsten and electrode temperature

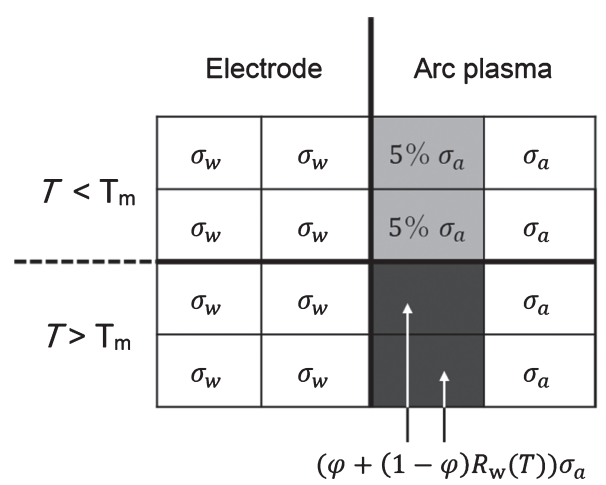

Fig. 7 Concept of the electrical conductivity on the electrode surface boundary

表面占有率および電気伝導率に対するタングステンの影響 度から決定される。

\section{3. 計算結果および考察}

\section{1 時間経過に伴う添加物の動的挙動}

まず，トリア入り電極を対象に溶接電流 $200 \mathrm{~A}$ の条件にお ける数值シミュレーションを行った.アーク点弧から 300 秒 後のティグ溶接モデルで得られた温度分布の計算結果を Fig. 8 に, 電極領域の詳細な温度分布と蒸発・拡散モデルで 得られたトリウムの濃度分布の計算結果を Fig. 9 に示す. アークプラズマは中心部において最高温度が $22460 \mathrm{~K}$ となっ ており，電極先端部は $10000 \mathrm{~K}$ を超える高温下にさらされて いることがわかる，一方，電極の温度は電極先端から上方 $0.4 \mathrm{~mm}$ までの範囲においてトリアの融点である $3323 \mathrm{~K}$ を超 えているが，先端の極一部を除く広い範囲ではタングステ ンの融点である $3653 \mathrm{~K}$ 以下に抑えられている。 また，軸方 向に比べ半径方向の温度勾配は小さいことがわかる。トリ ウムの濃度はトリアの融点を超えた領域の電極表面を中心 に低下がみられた。これは電極表面においてトリウムが外 


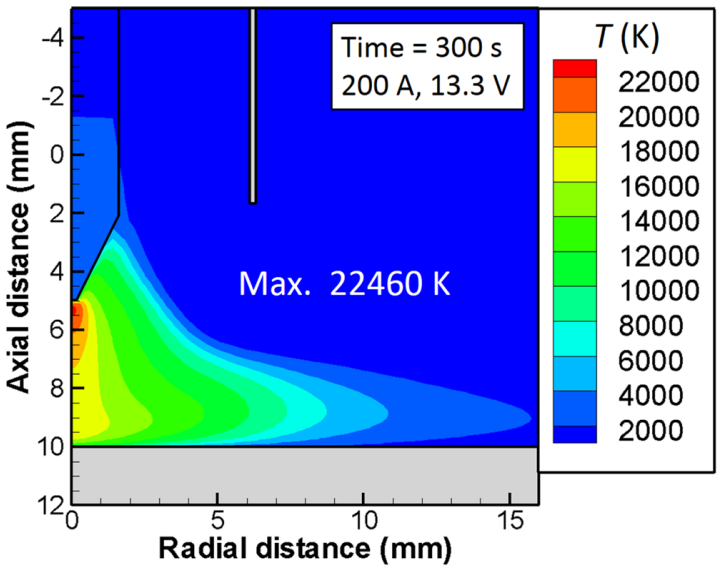

Fig. 8 Calculation result of the temperature distribution

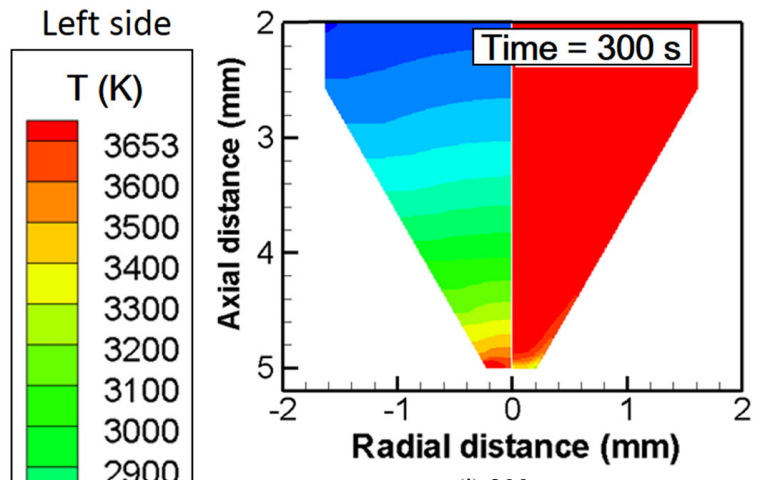

(i) $300 \mathrm{~s}$

2800

2700

2600

2500

2400

2300

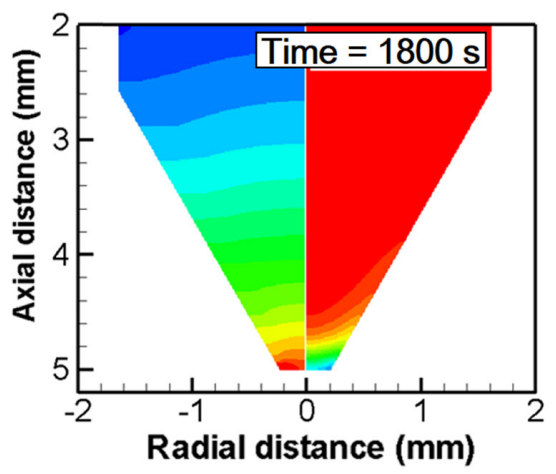

(iii) $1800 \mathrm{~s}$

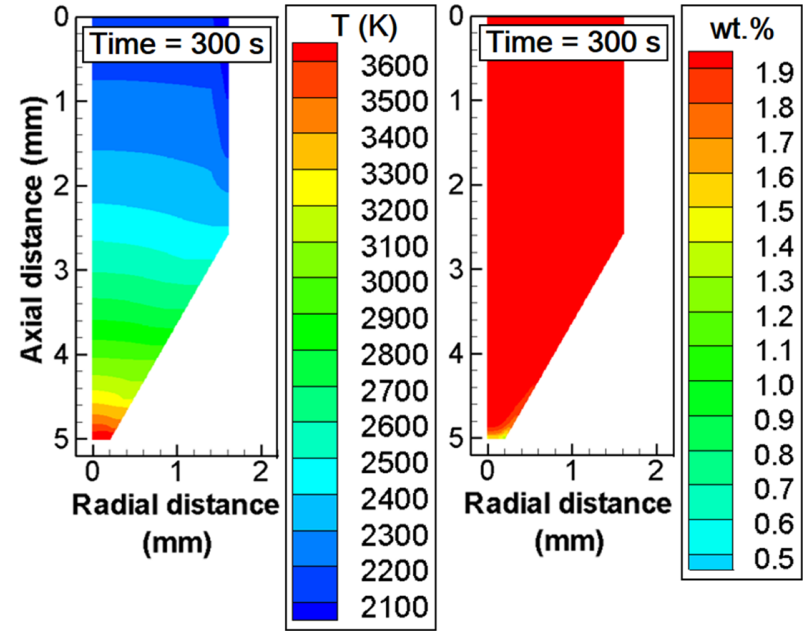

(i) Temperature

(ii) Mass concentration

Fig. 9 Calculation results of (i) temperature distribution and (ii) mass concentration distribution of additive

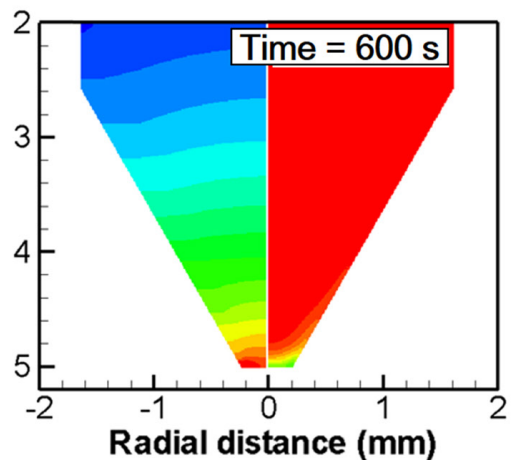

(ii) $600 \mathrm{~s}$

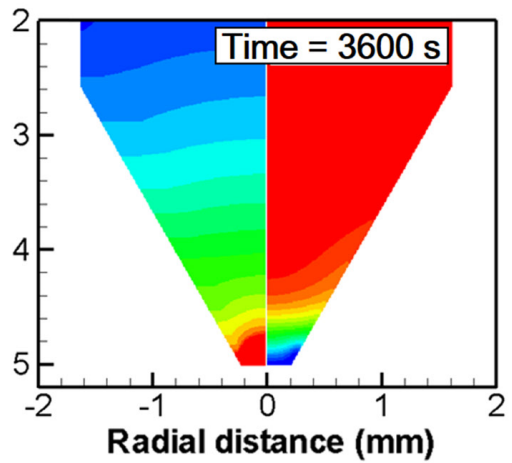

Right side

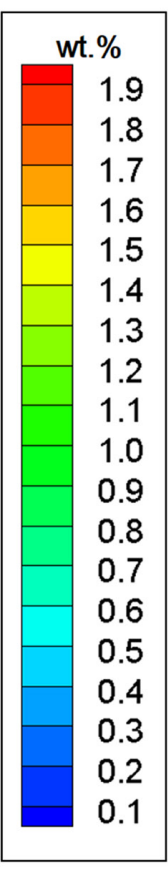

(iv) $3600 \mathrm{~s}$

Fig. 10 Calculation results of temperature distributions (left side) and mass concentration distributions of additive (right side) at the time of $300 \mathrm{~s}, 600 \mathrm{~s}, 1800 \mathrm{~s}$ and $3600 \mathrm{~s}$

部へ蒸発していること，またそれに伴い電極内部のトリウ ムが表面へ拡散によって供給されていることを意味してい る。特に面取りした角の部分（Fig.2のB）では，電流密度 が高くジュール発熱が大きいためトリウムの蒸発が盛んに 行われ，その結果最もトリウムの濃度が低下している。 以 上のことから，トリア入り電極ではトリアの融点を超える 領域においてトリウムの蒸発速度が拡散による供給速度を
上回り, 電極表面ならびに電極内部のトリウムの濃度が低 下することが明らかとなった。

Fig. 10 にアーク点弧から $300,600,1800$ ならびに 3600 秒 後の電極の温度分布およびトリウムの濃度分布の計算結果 を示す。トリウムが電極表面から蒸発するため時間経過と ともに電極先端部のトリウムの濃度は減少しており, 1800 秒後に 0.5 wt. \% , 3600 秒後には 0.1 wt. \% 以下となっている. 
また, トリウムの濃度が低下している領域は時間経過に伴 い電極表面から電極内部へと拡大している. 一方, 電極の 温度はアーク点弧から 1800 秒後までの間, トリウムの濃度 変化に影響されずほぼ一定の值となっていることがわかる. これは電極表面が融点を超えて液体となったトリウムに よって完全に覆われた状態,つまりトリウムの表面占有率 が $\varphi=1.0$ を満たしており, 安定した電子放出が持続されて いるからである. しかし, アーク点弧から 3600 秒後では夕 ングステンの融点を超える領域が大きく増加している.こ のように電極先端の広い領域がタングステンの融点を超え ると, 電極先端は溶融によって球状に大きく変形しアーク プラズマが不安定となるため, 電極の研磨や交換といった メンテナンスが必要となる. 本研究ではこの時間経過に伴 う電極の温度変化に着目し, 中心軸上の電極先端から $0.1 \mathrm{~mm}$ 上方の位置における電極温度がタングステンの融点を超え た時点を電極の寿命と定義した. タングステン電極の電極 寿命に関しては3.2節で考察する.

次に電極先端の温度変化が大きい 1800 秒後から 3600 秒 後までの蒸発および拡散現象を詳しく議論する. Fig. 11 に アーク点弧から $1800,2400 ， 3000$ ならびに 3600 秒後の電 極先端から上方 $0.4 \mathrm{~mm}$ の範囲におけるトリウムの表面占有 率および濃度分布の計算結果を示す。この範囲の電極表面 温度はアーク点弧直後からトリアの融点を超えているため 電極表面は液体のトリウムに覆われ表面占有率は 1 となっ ている ${ }^{19,20)}$. アーク点弧から 1800 秒後では電極の面取りし た角の部分においてトリウムの濃度は最も低く 0.3 wt. \% と
なっているが, トリウムの表面占有率は低下しておらずト リウムが表面を完全に覆っている状態である。しかし， 2400 秒後では面取りした角の部分においてトリウムの濃度 は $0.1 \mathrm{wt} . \%$ 以下となり,トリウムの表面占有率は 0.75 となっ た. 3000 秒後では面取りした先端部全域においてトリウム の濃度が $0.1 \mathrm{wt}$ \% \% 以下となり，トリウムの表面占有率は 1.0 を下回っている. 3600 秒後の結果ではトリウムの濃度が 0.1 wt. \% 以下となる範囲は, 先端から $0.2 \mathrm{~mm}$ 上方まで拡が りトリウムの表面占有率も同様の範囲で低下している.こ れらの結果からトリウムの濃度が $0.1 \mathrm{wt}$ \% \% 以下になると電 極表面への拡散によるトリウムの供給速度が低下し, 蒸発 による減少と拡散による供給のバランスが崩れることでト リウムの表面占有率が低下し始めると考えられる。また， 表面占有率の低下は面取りした角の部分から面取り部およ び円錐部へと拡がっていくことが明らかとなった.

Fig. 12 にアーク点弧から 1800, 2400, 3000 ならびに 3600 秒後における電極先端の温度分布の計算結果を示す。いず れの場合においても電極の円柱部の温度は $2500 \mathrm{~K}$ 以下と なっている．また，トリアの融点を超える範囲は 1800 秒後 では電極先端から $0.40 \mathrm{~mm}$ 上方まで, 3600 秒後では電極先 端から $0.46 \mathrm{~mm}$ 上方までとなっており, 時間経過による変 化はそれほど大きくないことがわかる，一方で，電極寿命 の評価位置とした電極先端から $0.1 \mathrm{~mm}$ 上方の点においては, 電極温度が 1800 秒後で $3575 \mathrm{~K}$ であるのに対し, 2400 秒後 では $3726 \mathrm{~K}, 3000$ 秒後では $4191 \mathrm{~K}$ と変化しており，時間経 過に伴い温度上昇が進んでいることがわかる. 3600 秒後で

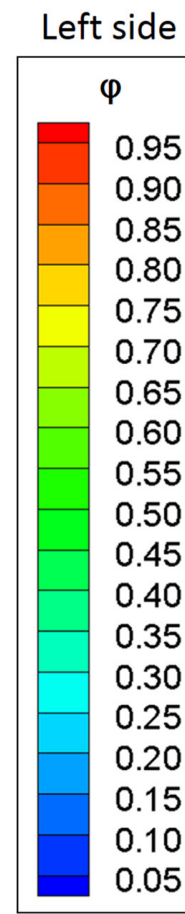

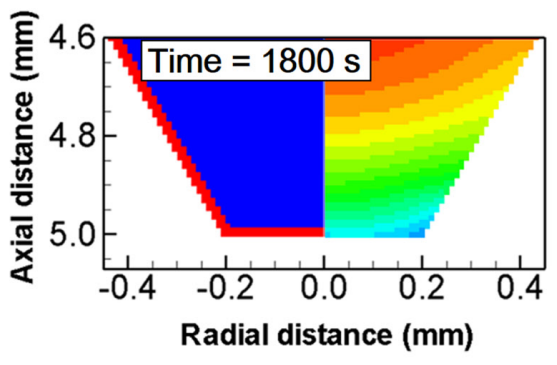

(i) $1800 \mathrm{~s}$

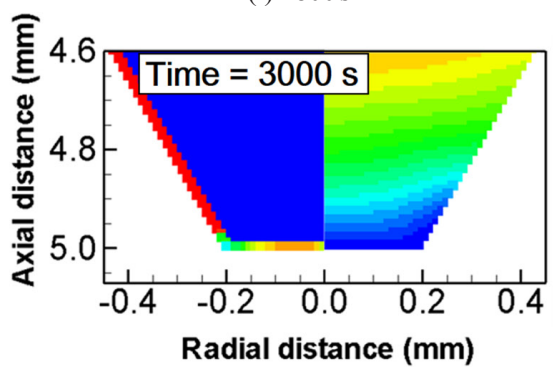

(iii) $3000 \mathrm{~s}$

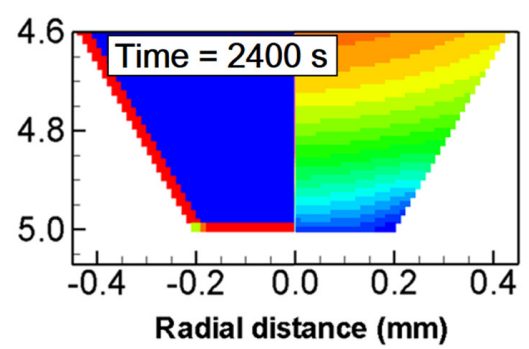

(ii) $2400 \mathrm{~s}$

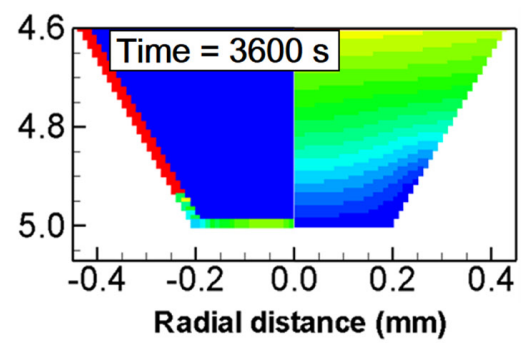

(iv) $3600 \mathrm{~s}$

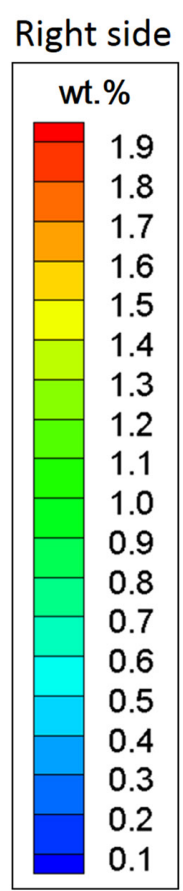

Fig.11 Calculation results of degree of coverage (left side) and mass concentration distributions of additive (right side) at the time of $1800 \mathrm{~s}, 2400 \mathrm{~s}, 3000 \mathrm{~s}$ and $3600 \mathrm{~s}$ 
は電極温度は $4271 \mathrm{~K} に$ 達しており, 1800 秒後に比べて約 $700 \mathrm{~K}$ の温度上昇が確認できる.

以上の計算結果から, 電極の温度上昇は電極先端の狭い 範囲に限られおり，その範囲はトリウムの表面占有率が低 下している範囲と一致していることがわかる。このように, トリウムの表面占有率が低下した範囲で電極温度が上昇し た理由は以下のように考えられる。前述のようにタングス テン電極には電子放出を容易にするためにタングステンに 比べて仕事関数の低いトリウムを添加しており，このトリ

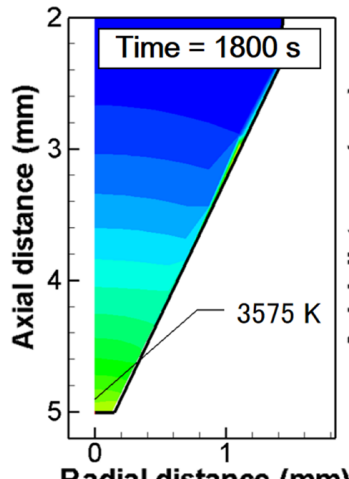

(i) $1800 \mathrm{~s}$

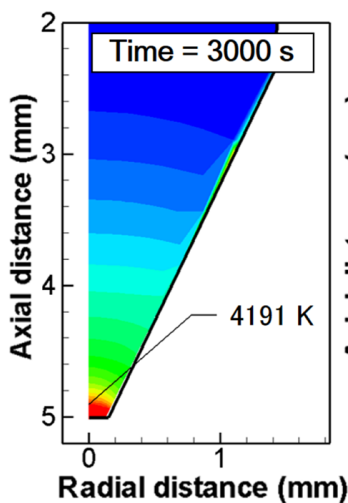

(iii) $3000 \mathrm{~s}$

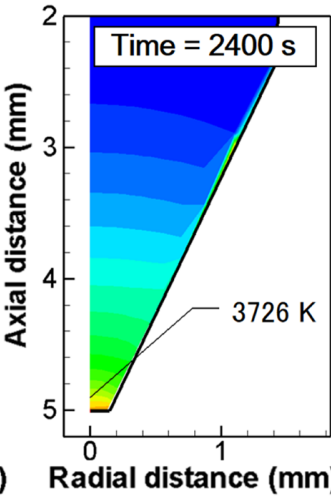

(ii) $2400 \mathrm{~s}$

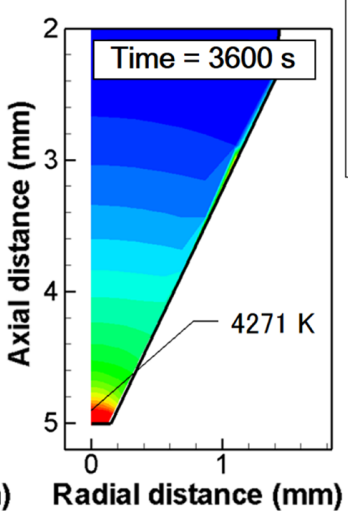

(iv) $3600 \mathrm{~s}$
Fig.12 Calculation results of temperature distributions at the time of $1800 \mathrm{~s}, 2400 \mathrm{~s}, 3000 \mathrm{~s}$ and $3600 \mathrm{~s}$
ウムが電極表面を完全に覆っている場合，電極は電子放出 によって冷却され溶融することなく安定したアーク放電を 維持できる。しかし，トリウムの表面占有率が低下すると 電極の仕事関数が増加し電子放出が生じにくくなるため, 電極の冷却作用が小さくなり高温のアークプラズマにさら された電極は温度上昇を引き起こす。

電極表面における添加物の分布形態の変化をまとめた模 式図を Fig. 13 に示す。アーク点弧前においてまんべんなく 存在している添加物はアーク点弧すると同時に溶融し，電 極先端部の表面を完全に覆うように分布する。このとき電 極表面では拡散による添加物の供給および蒸発による添加 物の損失が同時に生じている。一方，アーク点弧から時間 が経過すると添加物の供給速度が低下し，電極先端部にお いて添加物の損失が顕著になる。添加物が欠乏した電極先 端部は仕事関数が増加するため温度が上昇し，タングステ ンの融点を超えると形状変化を伴いながら急速に消耗して い.

\section{2 タングステン電極の寿命評価}

Fig. 14 にトリウムの表面占有率と電極寿命の評価位置に おける温度の時間変化を示す。ただし，トリウムの表面占

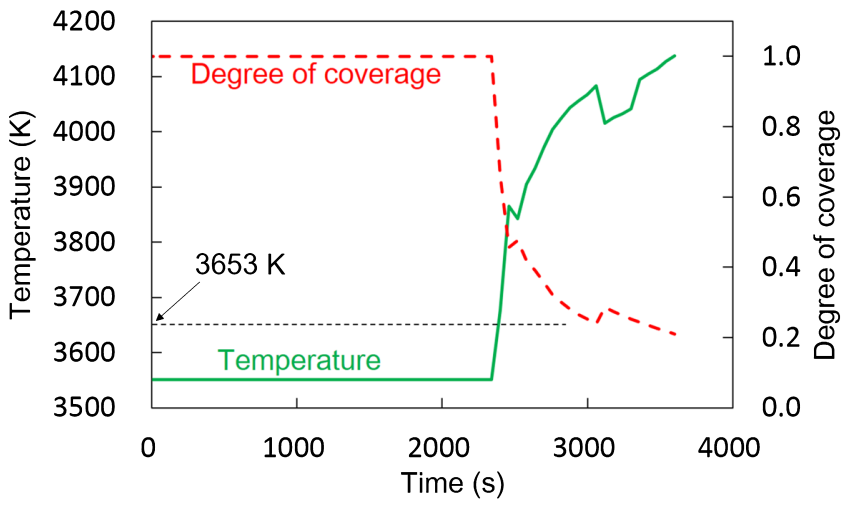

Fig.14 Changes of the electrode temperature and the degree of coverage with the time progress

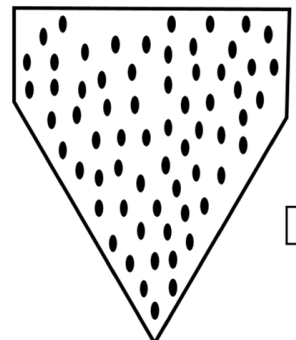

(i) Before arc discharge
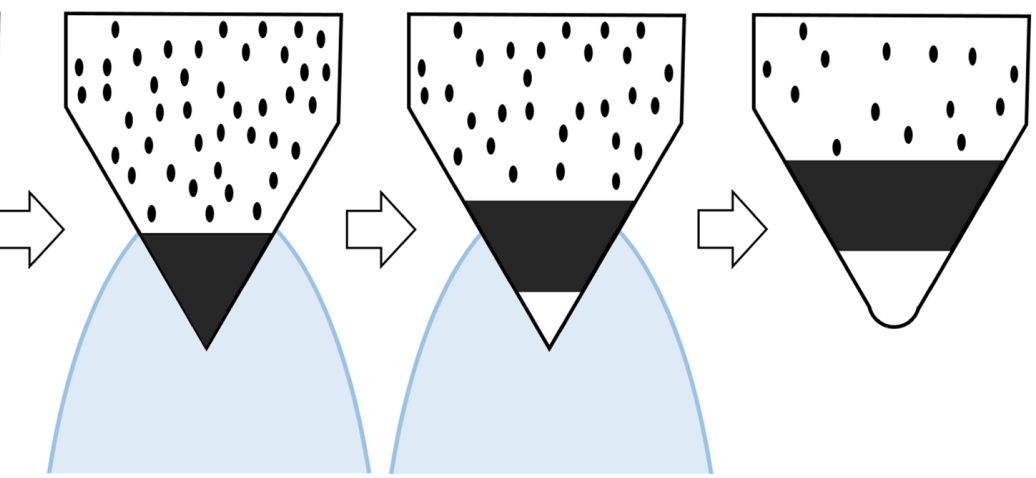

(ii) During arc discharge (iii) After arc discharge

Fig. 13 Schematic illustrations of consumption process of the electrode 
有率は面取りした角の部分における值を示している。アー ク点弧から 2400 秒後までは電極温度は一定の值であるが, 2400 秒後においてトリウムの表面占有率が低下するのに伴 い電極温度は急激に上昇し始め, 1 タイムステップ後である 2460 秒の時点でタングステンの融点を上回り $3856 \mathrm{~K}$ に達し ている.つまり，この条件におけるトリア入り電極の寿命 は2460 秒であると言える.また, Fig. 14 から電極の消耗は 一度始まると急激に進行していくことがわかるが, これは 表面占有率の低下に伴う温度上昇により表面からの蒸発速 度が上昇し，さらに表面占有率が低下するためである。

続いて, 添加物の物性值が電極の寿命に与える影響を検討 するため, トリア入り電極に加えランタナおよびセリア入り 電極について計算を行った. Table 1 に計算に用いた各添加 物の物性值を示す. ランタンの吸着熱 $H$ は Miedema ら ${ }^{21)}$ の 研究に基づく值を用い, セリウムの活性化エネルギー $Q$ と 拡散定数 $D_{0}$ は文献值 $^{10)}$ を用いた. Table 1 の括弧つきの物性 值に関しては, トリアに比べてランタナおよびセリアに関 する研究が少なくその物性值の入手が困難であったため,

Table 1 Physical properties of Th, La and Ce for the unified model

\begin{tabular}{ccccccc}
\hline & $\mathrm{T}_{\text {melt }}(\mathrm{K})$ & $\Phi(\mathrm{eV})$ & $\mathrm{Q}(\mathrm{J} / \mathrm{mol})$ & $\mathrm{D}_{0}\left(\mathrm{~m}^{2} / \mathrm{s}\right)$ & $\mathrm{H}(\mathrm{eV})$ & $\varepsilon$ \\
\hline $\mathrm{Th}$ & 3323 & 2.8 & $3.93 \times 10^{5}$ & $1.13 \times 10^{-4}$ & 7.1 & $1.4 \times 10^{-2}$ \\
\hline $\mathrm{La}$ & 2490 & 3.1 & $\left(3.93 \times 10^{5}\right)$ & $\left(1.13 \times 10^{-4}\right)$ & 6.0 & $\left(1.0 \times 10^{-3}\right)$ \\
\hline $\mathrm{Ce}$ & 2873 & 3.2 & $4.26 \times 10^{5}$ & $2.88 \times 10^{-6}$ & $(6.0)$ & $\left(1.0 \times 10^{-3}\right)$ \\
\hline
\end{tabular}

他の添加物の物性值を用いた。 具体的には, ランタンの活 性化エネルギー $Q$ と拡散定数 $D_{0}$ にはトリア入り電極と比較 しやすいようにトリウムの物性值を用いた. セリウムの吸 着熱 $H$ には酸化物の融点が近く, アーク点弧直後の電極温 度分布が似ているランタンの物性值を用いた。 また， $\varepsilon$ は吸 着を考慮した場合の蒸発の係数であり, Nemchinsky ${ }^{11)}$ の 研究において $\varepsilon=10^{-2}-10^{-3}$ としていることを参考にランタ ンおよびセリウムには $\varepsilon=1.0 \times 10^{-3}$ を使用した.さらに, 各酸化物の融点および仕事関数は田中ら ${ }^{5)}$ の研究と同じ值を 使用した。

Fig. 15 にトリア, ランタナならびにセリア入り電極の電

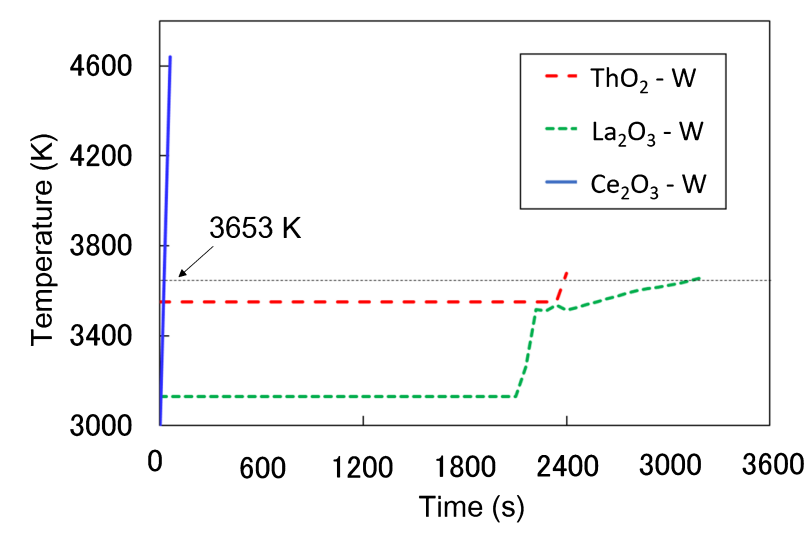

Fig. 15 Changes of the electrode temperature with the time progress
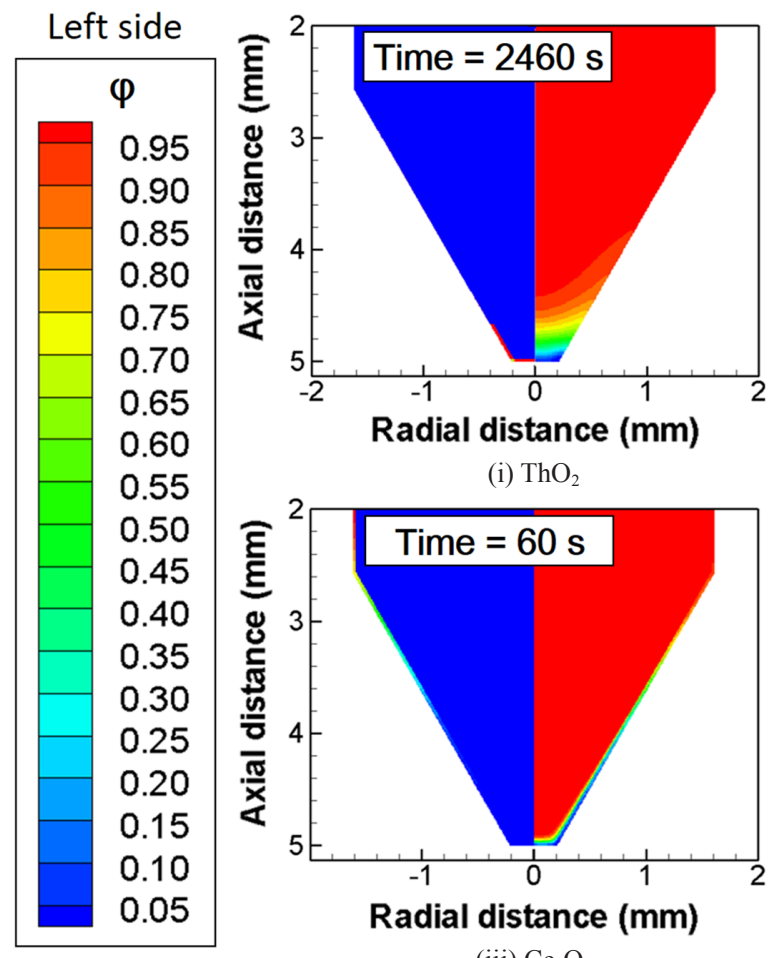

(i) $\mathrm{ThO}_{2}$

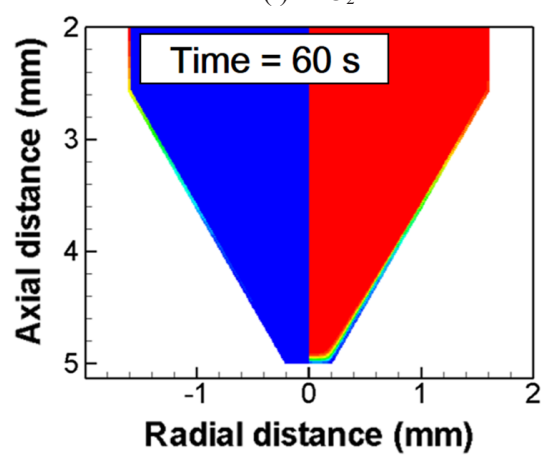

(iii) $\mathrm{Ce}_{2} \mathrm{O}_{3}$

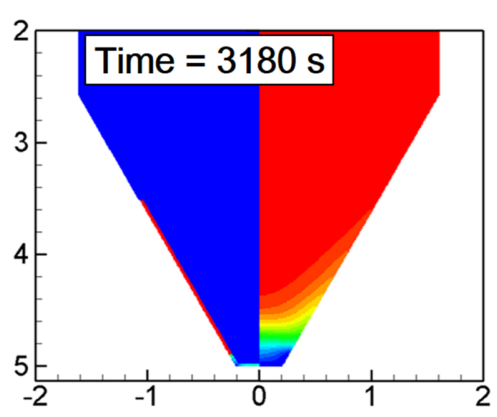

Radial distance $(\mathrm{mm})$

(ii) $\mathrm{La}_{2} \mathrm{O}_{3}$

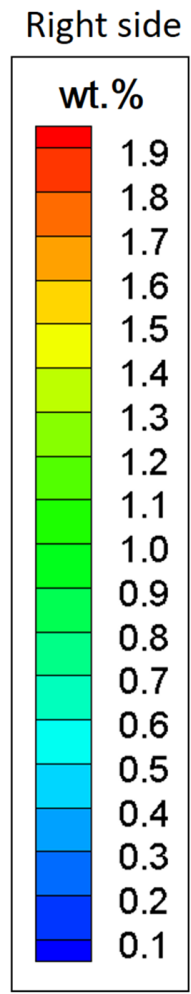

Fig. 16 Calculation results of degree of coverage (left side) and mass concentration distributions of additive (right side) at the life time of the electrodes 
極寿命の評価位置における温度の時間変化を, Fig. 16 に各 電極が寿命に達した時点における添加物の表面占有率およ び濃度分布を示す。ただし，それぞれの電極に関して酸化 物の融点以下の電極表面では添加物が溶融していないもの と考え, 添加物の表面占有率を体積占有率と同じ 0.05 とし ている.アーク点弧直後の電極温度はトリア入り電極で $3551 \mathrm{~K}$, ランタナ入り電極で $3128 \mathrm{~K}$, セリア入り電極で $2977 \mathrm{~K}$ となっており, トリア入り電極の電極温度が最も高 い. 一方で, 電極寿命はトリア入り電極で 2460 秒, ラン夕 ナ入り電極で 3180 秒, セリア入り電極では 60 秒となって おり, 電極寿命に関して添加物の種類によって異なるアー ク点弧直後の電極温度の影響は小さいことがわかる.

ここからはセリア入り電極ならびにランタナ入り電極に おける添加物の挙動をトリア入り電極と比較することで電 極寿命に大きな影響を与える因子を考察する．まず，セリ ア入り電極ではアーク点弧後わずか 60 秒にもかかわらずセ リウムの濃度は電極表面の広い範囲で大きく低下しており, 円錐部全体においてセリウムの表面占有率が 1.0 を下回って いる.これは Table 1 に示すようにセリウムの拡散定数が小 さいことに加え, アーク点弧時のセリア入り電極の電極温 度が低いため, 式(2)で計算されるセリウムの拡散係数が卜 リウムのそれに比べて極めて小さくなり，蒸発によって消 失するセリウムに対して拡散によるセリウムの供給が追い つかなくなる結果, 表面近傍においてセリウムが久乏した ためである。

次に, ランタナ入り電極は Fig. 15 からわかるようにトリ ア入り電極に比べて添加物の表面占有率が低下するまでの 時間がやや短くなっている。 これはランタンの吸着熱がト リウムに比べ低く, ランタンの蒸発速度がトリウムよりも 大きくなるためである，しかし，ランタナ入り電極の電極 温度は $3500 \mathrm{~K}$ まで急激に上昇した後, 温度上昇は緩やかに なり結果としてトリア入り電極よりも長い電極寿命を示し た.このランタナ入り電極の緩やかな消耗現象はランタン の表面占有率から以下のように説明される。 ランタナの融 点はトリアに比べて約 $800 \mathrm{~K} も$ 低いため Fig. 16 で示す表面 占有率からわかるように電極表面は広い範囲において溶融 したランタンによって覆われている.この場合, 電子放出 源が広く分布し電流経路は電極先端に集中するのではなく 電極の円錐部にまんべんなく拡がることができるため, 電 極先端においてランタンの表面占有率の低下が生じても電 極寿命に至るまでの急激な温度上昇はなく, 安定したアー ク放電が保たれる。しかしながら，その後の表面占有率の 更なる低下に伴い電極表面の仕事関数は緩やかに増加する ため電極温度も緩やかに上昇を続け, やがて電極寿命をむ かえる.

以上の結果より, 添加物の拡散定数, 吸着熱ならびに酸 化物の融点によって電極の寿命が大きく変化することが明 らかとなった。またこれらを踏まえ電極の長寿命化に必要 な条件としては, 添加物が拡散により電極先端へ供給され
やすいこと, 酸化物の融点が低く電子の電子放出源が電極 表面を広く覆うことで電流経路が電極先端に集中しにくい こと, 添加物の拡散速度に対してその蒸発速度が比較的小 さいことが挙げられる.

\section{4. 結言}

本研究では耐消耗性に優れたより良い電極の開発に向け て, ティグ溶接中の電極における添加物の拡散, 蒸発現象 について二次元空間での数值シミュレーションを行った. また，電極の長寿命化にも着目し，電極の寿命に大きな影 響を与える因子を調査した。 以下に本研究により得られた 主な知見を記す。

（1）トリア入り電極ではトリアの融点を超える領域において トリウムの蒸発速度が拡散による供給速度を上回り，電 極表面ならびに電極内部のトリウムの濃度が低下する.

（2）トリウムの濃度が $0.1 \mathrm{wt} . \%$ 以下になると電極表面への 拡散によるトリウムの供給速度が低下し, 蒸発による減 少と拡散による供給のバランスが崩れることでトリウム の表面占有率が低下し始める。また，表面占有率の低下 は面取りした角の部分から面取り部および円錐部へと拡 がる.

（3）電極の温度上昇は電極先端の狭い範囲に限られおり，そ の範囲はトリウムの表面占有率が低下している範囲と一 致する.

（4）電極の消耗は一度始まると急激に進行していくが，これ は表面占有率の低下に伴う温度上昇により表面からの蒸 発速度が上昇し, さらに表面占有率が低下するためであ る.

（5）電極の寿命は添加物の拡散定数，吸着熱ならびに酸化物 の融点等の物性值によって大きく変化する．電極の長寿 命化に関して拡散定数は電極表面への添加物の供給が十 分となる程度に大きいことが望ましい. 一方で添加物の 蒸発速度は小さい方が電極消耗が抑えられるため, 吸着 熱は大きいことが望ましい，また，酸化物の融点は添加 物の表面占有率を高く保つ上では低い方が良い。

\section{参 考 文 献}

1) A. A. Sadek, M. Ushio and F. Matsuda: Effect of Rare Earth Metal Oxide Additions to Tungsten Electrodes, Metallurgical Transactions A, Vol. 21A (1990) 3221-3236.

2) K. Tanaka, F. Matsuda and M. Ushio: Effect of Additives in Tungsten Electrode -Consumption of Electrode Tip at Relative High CurrentQuarterly Journal of the Japan Welding Society, Vol. 13, No. 4 (1995) 524-531.

3) K. Yamamoto, M. Tanaka, S. Tashiro, K. Nakata, K. Suzuki and K Yamazaki: Numerical Modeling of Welding Arc with Complex System between Arc Plasma and Molten Electrode, Materials Science Forum, Vol. 580 (2008) 311-314.

4) J. Haidar and A. J. D. Farmer: Surface temperature measurements for tungsten-based cathodes of high-current free-burning, Journal of Physics D: Applied Physics, Vol. 28 (1995) 2089-2094. 
5) M. Tanaka, K. Yamamoto, S. Tashiro and J. J. Lowke: Predictions of current attachment at thermionic cathode for TIG arcs, Materials Science Forum, Vol. 580 (2008) 319-322.

6) E. Casado and V. Colomer: The numerical modelling of Joule heating effects in thoriated tungsten cathodes of high-current plasma arcs, Journal of Physics D: Applied Physics, Vol. 33 (2000) 1342-1347.

7) M. R. Andrews: The evaporation of thorium from tungsten, Physical Review, Vol. 33, No. 3 (1929) 454

8) H. Nishiyama, T. Sato and K. Takamura: Performance Evaluation of Arc-Electrodes Systems for High Temperature Materials Processing by Computational Simulation, ISIJ International, Vol. 43, No. 6 (2003) 950-956.

9）深川修吉: 真空管材料 · 超高真空技術, オーム社 (1956) 第 4 章.

10）足立吟也：レアメタル便覧，丸善（2011）第 13 章.

11) V. A. Nemchinsky: Life time of a refractory cathode doped with a work-function-lowering dopant, Journal of Physics D: Applied Physics, Vol. 29, No. 9 (1996) 2417.

12) L. E. Belousova: Effect of the temperature of a tungsten electrode on the activation depletion time, Soviet Physics Technical Physics, Vol. 25 (1980) 471-473.

13) E. P. Gyftopoulos and J. D. Levine: Work function variation of metals coated by metallic films, Journal of Applied Physics, Vol. 33 , No. 1 (1962) 67-73.
14) S. V. Patankar: Numerical heat transfer and fluid flow, New York: McGraw-Hill (1980).

15）荒川忠一：数值流体工学, 東京大学出版会（1994）第 2 章.

16) J. P. Van Doormaal and G.D. Raithby: Enhancements of the simple method for predicting incompressible fluid flow, Numerical Heat Transfer, Vol. 7, No. 2 (1984) 147-163.

17) A. B. Murphy and C. J. Arundell: Transport Coefficients of Argon, Nitrogen, Oxygen, Argon-Nitrogen, and Argon-Oxygen Plasmas, Plasma Chemistry and Plasma Processing, Vol. 14, No. 4 (1994) 451-490.

18) J. J. Lowke, R. Morrow and J. Haidar: A simplified unified theory of arcs and their electrodes, Journal of Physics D: Applied Physics, Vol. 30, No. 14 (1997) 2033-2042.

19）田代真一, 田中学：アーク溶接の電極および溶融池現象, Journal of Plasma and Fusion Research, Vol. 88, No. 7 (2012) 383388.

20) M. Tanaka, M. Ushio, M. Ikeuchi and Y. Kagebayashi: In situ measurements of electrode work functions in free-burning arcs during operation at atmospheric pressure, Journal of Physics D: Applied Physics, Vol. 38, No. 1 (2005) 29-35.

21) A. R. Miedema and J. W. F. Dorleijn: Quantitative predictions of the heat of adsorption of metals on metallic substrates, Surface Science, Vol. 95, No. 2 (1980) 447-464. 